\title{
Towards an institutionalized language policy for the French Basque country? Actors, processes and outcomes
}

European Urban and Regional Studies 19(4) 434-447

(C) The Author(s) 2011

Reprints and permission: sagepub.co.uk/journalsPermissions.nav DOI: I0.1 I77/09697764|I428497 eur.sagepub.com

@SAGE

\section{Jean-Baptiste Harguindéguy}

Universidad Pablo de Olavide, Spain

\section{Xabier Itçaina}

Institut d'Etudes Politiques, France

\begin{abstract}
This paper focuses on the progressive institutionalization of the Basque language policy (also called Euskera) in the French Basque Country (Iparralde) since the Second World War. In view of this, it questions how such a policy programme emerged in such a centralized country as France. According to this study, this policy shift was favoured not only by a combination of endogenous factors (for example, the new French territorial polity, the new institutional capacities reached after decentralization, the new relationship with central state services, the establishment of stable territorial coalitions between civil society and local representatives, the new and more peaceful repertoire of collective actions among activists) but also by exogenous variables (for example, the rise of cross-border relations between French and Spanish Basque actors). In sum, the strong political institutions and social movements of the southern Basque Country partially compensated for the institutional weakness of French Basque actors and contributed, along with endogenous factors, to the institutionalization of a specific language policy for Euskera.
\end{abstract}

\section{Keywords}

Basque Country, ethnonationalism, France, language policy, mobilization

\section{Introduction}

This paper focuses on the institutionalization process of the Basque language (also called Euskera) in France. Technically speaking, Basque is a regional language, that is, 'a tongue traditionally used within a given territory of a State by nationals of that State who form a group numerically smaller than the rest of the State's population; and different from the official language(s) of that State', according to the Council of Europe's criteria (1992). Euskera is one of the four non-Indo-European languages found in Europe, along with Finnish, Estonian and Hungarian. It is mainly spoken in the Basque Country, a territory located on the Atlantic coast and straddling the

\footnotetext{
Corresponding author:

Professor Jean-Baptiste Harguindéguy, Universidad Pablo de Olavide, Ed. 14, pl. 4, desp. 22, Seville, 4I0I3, Spain.

Email: jbhar@upo.es
} 
border between Spain (also called Hegoalde, the southern or 'Spanish' side, in Euskera) and France (Iparralde, the northern or 'French' side).

Language policy in France has generated increased literature over the last 35 years. The main political and sociolinguistic analyses have focused on the process of state- (and nation-) building carried out in France, which has progressively converted regional languages into lesser-used languages from the 1789 Revolution onwards (Blanchet et al., 1999; Clairis et al., 1999; Judge, 2000). In addition, sociologists have focused their attention on the mechanism of symbolic violence exerted by the French on the speakers of regional languages (Bourdieu, 1982) and on the rise of ethnolinguistic militancy in the late 1970s (Bourdieu and Boltanski, 1981; Touraine et al., 1981). The effects of the decentralization policy have also been assessed as a new political opportunity structure for regional languages by Loughlin (1985), Cole and Loughlin (2003), Harguindéguy and Ballester Lopez (2007) and Harguindéguy and Cole (2009). As a result, the changes that occurred in the 1990s gave rise to a series of technical reports for the prime minister (Poignant, 1998; Cerquiglini, 2003). Literature on Hegoalde language politics and policy (with some comparisons with Iparralde) is also very abundant (Linz et al., 1986; Tejerina, 1999; Baxok et al., 2006; Mezo, 2008). This is mainly owing to the consistent language policy implemented in the autonomous communities of Euskadi and Navarre, where Euskera has enjoyed co-official status since 1982 and 1986, respectively. In contrast, the empirical study of the Iparralde's Basque language policy began only in the early 2000s (Ahedo Gurrutxaga, 2004; Urteaga, 2004; Amado Borthayre, 2006). On the one hand, these analyses tended to reflect the rigid French policy, which formally precluded a national debate on the state of linguistic minorities; on the other hand, they also demonstrated that the French Republic was able to integrate some relevant projects at the local level. However, these research studies stopped in 2005 , and only a few of the studies developed a comprehensive analytical framework that is able to explain the recent developments in language policy.

This is a major problem because a specific language policy has emerged to promote Euskera in
France since the late 1990s (even if to a lesser degree than in Spain). Initially based on a set of different and puzzling initiatives, this policy has progressively become institutionalized. As with all coherent language policy programmes, it is based on three dimensions: status planning (which aims to enhance the prestige of a language by introducing its use in administration, at school and in the mass media), acquisition planning (to increase the number of speakers), and corpus planning (to create a homogeneous koine) (Fishman, 2000). This case cannot be compared with other large language planning policies such as those carried out in Quebec with French or in Israel with Modern Hebrew. Nevertheless, it constitutes an important first step towards official recognition in France, one of the most centralized countries of the European Union which still forbids the use of the term 'language minorities' to refer to the speakers of regional languages (Harguindéguy and Cole, 2009).

How did such a policy become possible in France? And what factors allowed this policy change? In order to understand this ongoing process of institutionalization, this paper develops a central hypothesis based on the analyses of various regional studies (Keating, 2001; Cole and Loughlin, 2003; Cole and Williams, 2004; Jones and Fowler, 2007). Most of these authors use common variables such as the level of decentralization enjoyed by territorial authorities or the consistency of local actors' networks. Nevertheless, this paper argues that on some occasions this analysis remains incomplete and additionally requires the adoption of an exogenous perspective. In this specific case, this study aims to demonstrate that, along with these endogenous factors, the language policy undertaken in France regarding Euskera has also been favoured by the rise of cross-border links between Iparralde's actors and their counterparts from Hegoalde. For further discussion of cross-border issues in Europe see Kuus (2011). From this perspective, exogenous resources would have partially compensated for the institutional weakness of French Basque actors.

This research has been funded by the Regional Council of Aquitaine (Programme 'Vers une gouvernance transfrontalière en réseau? Les expériences du tiers secteur dans les territoires frontaliers basque et irlandais, 2010-2014') and was undertaken in 


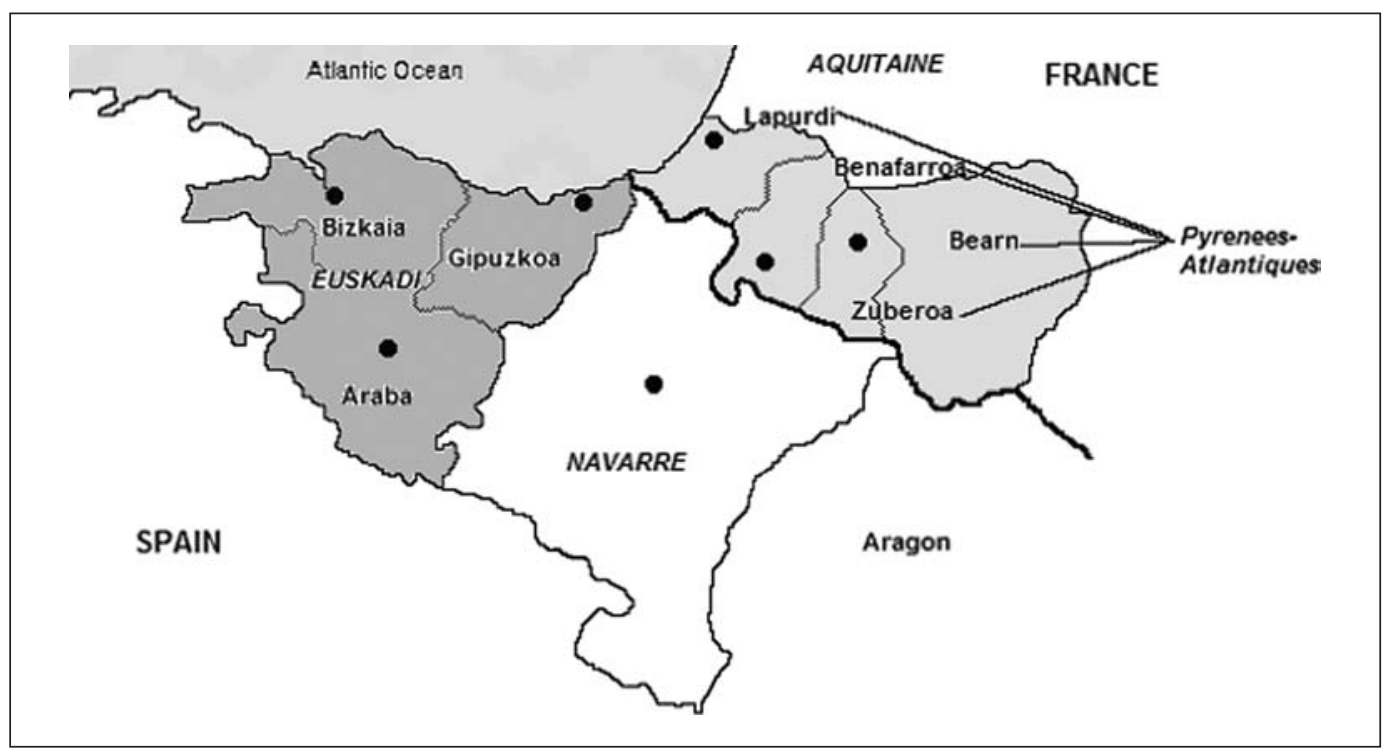

Figure I. The Basque provinces

various steps. It began in 2002 with 30 unstructured interviews in the French Basque Country, which were followed by the establishment of contacts with Spanish Basque institutions and social movements in 2004 (11 actors were interviewed) and by the scientific participation in the 2005 cross-border survey on Basque culture and identity (Baxok et al., 2006). Finally, the data were updated in 2008, 2009 and 2011 through 15 new interviews. Grey literature and local newspapers were used as secondary sources.

The paper is organized as follows. We first present the empirical evidence of the institutionalization of a Basque language policy in France and then analyse the roots of this policy shift. Finally, brief conclusions are used to draw out the theoretical implications of these developments.

\section{The institutionalization of the Basque language policy in Iparralde}

As stated earlier, Euskera in France is now supported by a set of language provisions aiming to reinforce its prestige, to increase its number of speakers, and to give more cohesion to its morphology. At first glance, the results observed in the research field are quite varied in the sense that some bilingual improvements have occurred in specific niches (for example, in immersion education), whereas other sectors remain entirely in French (local administration, for instance).

In terms of absolute numbers, Basque is mainly spoken in the autonomous communities of Euskadi (encompassing the administrative provinces of Bizkaia, Gipuzkoa and Araba) and Navarre (a monoprovincial autonomous community). These political divisions approximately coincide with the four major dialectal subdivisions of the Basque language in Spain. Basque is also used in France in the département of Pyrénées-Atlantiques, which is one of the five départements forming the Aquitaine region. Pyrénées-Atlantiques is an administrative territorial subdivision created in 1790 by French revolutionaries who sought to group the Bearn (Occitan-speaking) area with the three French provinces of the Basque Country (Zuberoa, Benafarroa and Lapurdi, in Basque) to avoid irredentist and monarchist claims. These three provinces approximately correspond to the three dialectal areas of Basque in France (Baxok et al., 2006) (Figure 1). Following the Congress of Arantzazu (1968), a standardized Basque (called Batua: unified) was agreed upon by the Euskaltzaindia (Royal Academy of the Basque Language), which was founded in 1919 by Basque intellectuals from France and Spain. 
Table I. Proportion of Basque speakers in Spain

\begin{tabular}{lllll}
\hline & $\begin{array}{l}\text { Bilingual } \\
\text { (percent) }\end{array}$ & $\begin{array}{l}\text { Passive bilingual } \\
\text { (percent) }\end{array}$ & $\begin{array}{l}\text { Not in contact with } \\
\text { Basque (percent) }\end{array}$ & Total no. of inhabitants \\
\hline Hegoalde & 25.5 & 16.2 & 58.3 & $2,359,400$ \\
Euskadi & 30.1 & 18.3 & 51.5 & $1,850,500$ \\
Bizkaia & 23 & 19.4 & 57.6 & \\
Gipuzkoa & 49.1 & 15.9 & 35.0 & 508,900 \\
Araba & 14.2 & 20.0 & 65.8 & \\
Navarre & 11.1 & 7.6 & 81.3 & \\
\hline
\end{tabular}

Source:Viceconsejería de Política Lingüística (2006).

Table 2. Proportion of Basque speakers in France

\begin{tabular}{lclll}
\hline & $\begin{array}{l}\text { Bilingual } \\
\text { (percent) }\end{array}$ & $\begin{array}{l}\text { Passive bilingual } \\
\text { (percent) }\end{array}$ & $\begin{array}{l}\text { Not in contact with } \\
\text { Basque (percent) }\end{array}$ & Total no. of inhabitants \\
\hline Iparralde & 22.5 & 8.6 & 68.9 & 230,200 \\
Lapurdi (coast) & 8.8 & 5.4 & 85.8 & \\
Lapurdi (hinterland) & 25.6 & 11.3 & 63.1 & \\
Zuberoa/Benafarroa & 55.5 & 10.7 & 33.8 & \\
\hline
\end{tabular}

Source: Viceconsejería de Política Lingüística (2006).

As the IV Sociolinguistic Report of the Government of Euskadi (Viceconsejería de Política Lingüística, 2006) states, the highest percentage of Basque language speakers can be found in Euskadi, Iparralde and Navarre. Although Iparralde is still losing speakers over 65 (who represent almost 40 percent of the total speakers in the hinterland), the trend has changed, with new young speakers appearing thanks to efforts in the field of education. However, French remains the mother tongue for 72.3 percent of Iparralde inhabitants. Although 41.2 percent of Iparralde inhabitants are favourable to the use of Basque, French is used in 77.4 percent of social interactions (for example, business, family, administration). This is especially the case on the Basque coast, in large part because of the rapid urbanization process taking place from the north of Bayonne to Saint-Jean-de-Luz, which attracts immigrants (with contrasting socioeconomic profiles ) from the rest of France (Tables 1 and 2). It is also worth mentioning that there is a strong correlation between the ability to speak Basque and a feeling of belonging to the Basque Country that cannot be assimilated into a nationalist identification, regardless of the territory or age in question (Viceconsejería de Política Lingüística, 2006).

Because of the lack of a real regional language policy until the 1990s, the promotion of Euskera in France has long been carried out by civil society organizations through different teaching and learning techniques. In the field of education, one of the first initiatives was led by the Catholic Church through the efforts of Bishop Gieure in the 1920s. After the Second World War, the Deixonne Act (1951) enabled the organization of Basque courses three hours per week as a second (or third) language in public schools. In 1975, the Haby Law confirmed this provision but, at the same time, the Bas-Auriol Law made it compulsory to use French in business and in the mass media (to bolster the institution of francophonie). Despite these limitations, the reforms of 1982 and 1995 enabled the teaching of Euskera through 'Regional Culture and Language' courses in public schools. In 1982, the Savary decree allowed private, 'contracted-in' schools to teach regional languages if public schools were not able to do so. 
As a result, since 1982, the Ikas-bi association has administered a system of bilingual teaching in public schools, and Euskal Haziak organizes a similar system in Catholic private schools.

This bilingual training is seen as the first step towards a BA degree course in Basque, as proposed by the Université de Pau et des Pays de l'Adour and the University of Bordeaux. Since 1969, a model of Basque learning by immersion has also been available, thanks to efforts of the Seaska Association and its ikastola schools (Jacob, 1994). In 1992, the Ministry of National Education recognized this initiative, and it restated the agreement in 2009 by co-funding part of the project. As expected, such official recognition of the ikastola generated debates between the supporters of this type of institutionalization and those who prioritized the social movement dimension of the ikastola (Borthayrou et al., 2005). The main association for adult language training in Iparralde is AEK (Alfabetatze Euskalduntze Koordinakundea - Coordination for Alphabetization in Euskera), which organizes courses, linguistic exchanges and immersion training camps for French students in its Euskadi and Navarrese branches (Oronos, 2002; Borthayrou et al., 2005; Oronos et al., 2008; Garat and Aire, 2009).

The presence of regional languages outside of the classroom has been greatly reduced. For example, road signs and postal addresses can be written in French and in the vernacular language, but Basque is practically absent from private business in France. Regarding the mass media, it may be noted that the Radio France public network broadcasts daily programmes in Basque in the area of Bayonne, although this is a recent and rather irregular initiative. Additionally, many associated radio stations (Gure Irratia in Lapurdi, Irulegiko Irratia in Benafarroa and Xiberoko Botza in Zuberoa) appeared in the 1980 s and use Euskera as their first language. Concerning TV channels, the France 3 national public channel provides only short news programmes in Basque. Nevertheless, the Spanish Basque channels Euskal Telebista 1 and 2 also broadcast their programmes to Iparralde and fund some correspondents in Bayonne. Newspapers distributed in Iparralde are written in French with only a few exceptions (such as the daily cross-border newspaper Berria or the
Christian-Democrat weekly Herria). On rare occasions, Sud-Ouest or La Semaine du Pays-Basque publish short articles in Euskera. Even French Basque nationalist newspapers such as Enbata are mainly written in French. Some publishing companies support the diffusion of Euskera, but this is a difficult task because Basque speakers represent a limited potential market, at least on the French side of the border (Oronos et al., 2008).

\section{The roots of the language policy shift: language at the core of the new territorial governance (1990-2010)}

\section{France, a hostile polity to regional languages?}

France is usually considered to be the archetype of the culturally centralized nation-state. The VillersCotterêts decree was implemented in 1539 by the Crown in order to substitute Latin for French and reinforce its control over administration (Elias, 1982). During the Revolution, a new step was taken towards language hegemony through an ambitious programme of language centralization for promoting the French language as the symbol of modernity against local dialects assimilated to the Church and the aristocracy. The leitmotif of state and nationbuilders became: 'One state, one nation, one language' (Judge, 2000). Linguistic unification was reached under the Third Republic, through the Ferry laws of 1881 and 1882, which banned regional languages from public schools. The emergence of a modern capitalist market, mass media and military conscription completed this process by imposing French as the national tongue in the whole country (Weber, 1977).

Under these conditions, it is interesting to note that the first regulations promoting vernacular languages in France - even if very weakly implemented were imposed by the pro-Nazi government led by Marshal Pétain in the 1940s (Barral, 1974). This delegitimization meant that the use of regional languages was forbidden in the French administration as late as 1974. This centralist credo was reaffirmed in 1992 with the addition of "The language of the Republic is French' to the French Constitution (Article 2) and 
again in 1994 through the Toubon Law, which implemented positive action measures to defend French against English in the public sphere.

Despite this context, several regional languages survived this drawn-out process of language rationalization: 75 regional languages are currently spoken in France, although only one-third are spoken in metropolitan France. Nowadays, Republican institutions tolerate the use and promotion of regional languages at the local level but are still reluctant to explicitly recognize the existence of language minorities. For instance, the General Delegation for the French Language of the Ministry of Culture converted into the General Delegation for the French Language and Languages of France in 2001. The National Assembly's deputies also included the clause that 'Regional languages are part of France's heritage' in Article 75 of the Constitution. However, the French government did not ratify the Council of Europe's 1992 Charter for Regional or Minority Languages (Wright, 2000).

\section{New relations between Basque actors and the central state}

At first glance, the institutionalization of a cultural and linguistic policy in the Basque Country benefited from the 1982 process of decentralization (and its further stages). At that time, President Mitterrand launched an ambitious programme of territorial empowerment. This project consisted of transferring more competencies and resources to the 36,680 city councils (mairies), the 100 departmental councils (conseils généraux) and the newly created 25 regional councils (conseils régionaux).

In this context, the French Basque Country has experienced an unusual pattern of territorial governance since the end of the 1980s that constituted much more than what scholars of Basque nationalism have called 'cosmetic decentralisation' (Mansvelt Beck, 2005) or a 'private type of institutionalisation' to compensate for the non-creation of a specific Basque département (which has been a historical demand by Basque activists since the 19th century) (Letamendia, 1997). First, the rise of the 'pays' Pays Basque in 1997 under the 1995 Law on Territorial Planning (Loi du 4 février 1995 d'orientation pour l'aménagement et le développement du territoire) was in accordance with the French decentralization policy. This designation was intended to promote local economic development through the existing territorial networks of private companies, associations and local authorities. The Basque experience has been seen since then as a good example of local development, and it has inspired the national policy of the pays led by the central state.

Secondly, the territorial institutionalization of the French Basque Country, far from being controlled or inspired by Basque nationalists, was rather the result of a permanent compromise between the various political leaders dominating the Basque territory in France (the French centre-right in the hinterland and the coastal area; the Socialist Party on the periphery of the largest cities, Hendaye and Saint-Jean-Pied-dePort; and some isolated Green leaders and Basque moderate nationalists) and the business milieu.

Thirdly, over the past 10 years, the new French Basque territorial institutions have had tangible effects on territorial governance, especially in linguistic and cultural matters. The efforts of the Basque Country Development Council (Conseil de développement du Pays basque), a new public body created by local notables, state representatives and civil society actors to elaborate a strategic plan for the Basque part of the département, to negotiate consensual territorial contracts involving the state, the Regional Council of Aquitaine, the General Council of the Pyrénées-Atlantiques and local authorities constitute evidence of its willingness to include and recognize all of the actors of Iparralde.

In sum, the institutional spur for the French Basque Country originated more in the changing territorial policy paradigm than in a significant shift in the state's linguistic policy. By giving more room for local experiences of territorial governance, the decentralization has given greater latitude to Basque local institutions, which have used these new powers to enhance a semi-autonomous linguistic and cultural policy.

\section{A local institutional empowerment process}

The debate over linguistic and cultural policy was at the heart of the governance shift experienced by 
the French Basque Country in the late 1980s. As indicated by an interviewed member of the General Council of Pyrénées-Atlantiques: 'paradoxically, this U-turn was launched by an initiative of the Pyrénées-Atlantiques' prefect' (the local representative of the central state in every département). This initiative consisted in organizing a series of consultations among local actors with very different backgrounds (leaders of civil society associations, elected representatives, Basque nationalists and non-nationalists, and so on).

These meetings gave birth to a scenario for the future of the French Basque Country entitled 'Pays Basque 2010' (Chaussier, 1996). Beyond the official rhetoric on local development and territorial networks, this state-driven initiative had a dual objective. First, it promoted consensual deliberation on local issues aimed at putting an end to a period signalled by a relatively high level of tension, including physical violence, in the French Basque Country even if with lower intensity than in Spain. The French Basque armed movement Iparretarrak (those of the north) was particularly active in the 1980s, as were the anti-terrorist squads of the GAL (Grupos Antiterroristas de Liberación - Counter-terrorist Liberation Squads) organized by the Spanish secret service to attack alleged members of ETA (Euskadi Ta Askatasuna) living in the French Basque Country. Additionally, the French central state needed to respond to demands for the creation of a specific Basque département by offering alternative institutional formulas. As a result, and in accordance with the participative volte-face induced by the French decentralization policy, new semi-public institutions soon emerged. The Basque Cultural Institute, the Basque Country Development Council and the Council for Elected Representatives (along with the Intermunicipal Community for the Basque Culture which linked 143 city councils) were set up in 1989, 1994 and 1995, respectively (Ahedo Gurrutxaga, 2005). These organizations were conceived as new debating arenas for local politicians and civil society representatives.

This process of territorial planning also had collateral effects on language policy. As mentioned previously, in 1997 the French Basque Country was officially recognized as a pays. As a result, the first territorial contract with this pays was signed in 1997 between local authorities and the state, and a Specific Agreement for the Basque Country (Convention spécifique Pays basque) was ratified among the state, regional and local authorities for the 2000-6 programming period. This partnership was renewed in early 2000, when a new consultation process ('Pays Basque 2020') generated a Territorial Development Programme (Schéma d'aménagement du territoire) and a Territorial Contract on Local Development (Contrat territorial de développement local) between the state and the territorial authorities in 2008. As a whole, this new form of territorial governance was largely open to civil society, especially with regard to issues usually managed by activist circles (for example, local development, agriculture, environment, culture and language).

At that time, the question of the Basque language progressively changed from a social issue into a public problem and then into a political problem (Lascoumes and Le Galès, 2007). At the very beginning of this process, in 1984, a Centre Culturel du Pays Basque (Cultural Centre for the Basque Country, $\mathrm{CCPB}$ ) was created to encourage the general diffusion and production of cultural events (including theatre, painting and music in French and Basque). But, in order to respond to the growing mobilization of nationalist associations, local elected leaders and language activists, the CCPB split in 1988. It reappeared as a 'generalist' cultural institution (the Centre d'Action Culturelle de Bayonne et du Sud-Aquitaine - Centre for Cultural Activity of Bayonne and the Southwest), on the one hand, and as an institution that is more specialized in Basque cultural matters (the Institut Culturel Basque - Basque Cultural Institute), on the other (Laborde, 1999).

This phenomenon of institutional instability caused the Basque language to be promoted by the semi-public Basque Cultural Institute, three private educational networks of Basque teaching schools (Seaska, Ikas-bi and Euskal Haziak) and the associated AEK centres. Because of the creation of these new tools, the fragmentation of language governance rapidly emerged as a problem. Institutional actors and activists thus asked for one specific institution that could implement the incipient linguistic policy to avoid the dilution of funding and initiatives. 
This was the real starting point of the institutionalization process of a Basque language policy in the French Basque Country. For the first time in France, the Basque language was included in a territorial development project within the Schéma d'aménagement du Pays basque (Development Programme for the Basque Country) in 1996-1997. Then, the Specific Agreement for the Basque Country within the state, the Aquitaine region, and the Pyrénées-Atlantiques département emerged in 1999-2000. Among other measures, AEK benefited from gaining its first official recognition as a vocational training body through the Specific Agreement. Public and tertiary sector actors met around a common programme of subsidies for promoting linguistic operators (2000-4) under the leadership of a newly created semi-public organization: the Council for the Basque Language (Conseil de la langue basque), which brought together the central state, the Aquitaine region, the Pyrénées-Atlantiques département and the Council of Elected Representatives). In November 2004, the Council for the Basque Language was converted into the Public Office for the Basque language (Office public de la langue basque, OPLB). The OPLB was created to fulfil a dual role by supporting and coordinating the supply of and demand for courses 'on' Euskera and 'in' Euskera, as well as by promoting the use of the language in society with the help of public authorities. Meanwhile, as early as 1999, the General Council of the PyrénéesAtlantiques also created a new internal subdivision dedicated to linguistic policy, both for the Basque and for the Occitan languages.

At that point, the promotion of Euskera was no longer the sole domain of a small group of social activists but instead constituted a specific policy programme led by public institutions. New developments occurred in 2000 when this new policy began to include sociolinguistic expertise. In 2000, the Specific Agreement for the Basque Country 2001-6 referred to Fishman's 'reversing language shift' concept as a potential theoretical basis for a new linguistic policy in the French Basque Country (Coyos, 2004, 2008). The threefold approach to language recovery (motivation/knowledge/use) developed by Spanish Basque sociolinguist José María Sánchez
Carrión 'Txepetx' was also introduced in Iparralde, notably by the French Basque sociolinguist Baxok (2008), who was himself familiar with other linguistic debates such as the Canadian one. However, the new institutions dealing with the Basque linguistic policy were to be guided more by pragmatic considerations and comparative benchmarking (with Quebec, Euskadi, Brittany, etc.) and by sociolinguistic surveys than by a standardized theoretical framework (interview, OPLB, Bayonne, 2011).

The new division of labour between language and cultural policies produced by this intensive process of institution-building raised some questions about the existing institutions. Until that time, mediation between ethnolinguistic activists and public authorities had been assumed by the Basque Cultural Institute for cultural matters and by Ikas-bi, Seaska and Euskal Haziak in the field of Basque teaching. Within the new framework, the Basque Cultural Institute had to determine its statute and its function: should it remain a publicly funded association or become a public body? More generally, what did 'Basque culture' mean in this new context? Did it refer to Basque-speaking cultural production? To any cultural production made by Basque artists? Or to any cultural production carried out in the Basque Country?

In any case, in 2011, six years after its foundation, the OPLB was able to evaluate its activity. Positive results were obtained concerning language transmission, notably concerning bilingualism in primary education, childcare and the initial linguistic policy at the local municipal level. For its planning for 2010-16, the OPLB admitted, in line with all of the sociolinguistic surveys, that its actions needed to be redirected towards the social and public uses of language and not only towards its transmission (interview, OPLB, Bayonne, 2011).

\section{The effects of territorial coalitions on language issues}

First of all, in France, the recent (though limited) politicization of the linguistic issue gave a new impetus to the strategic coalitions between representatives of the different French regional or minority languages, such as the FLAREP (Fédération pour 
les langues régionales dans l'enseignement public, whose members come from Brittany, Alsace, Occitane, Corsica, Catalonia, and so on) in the public education system or the Interregional Meeting for Minority Cultures and Languages (Rencontres interrégionales des langues et cultures minoritaires), a series of annual meetings used to strengthen claims for a new language deal in France.

Secondly, new coalitions appeared in the French Basque Country. The most visible was probably the network that links local public institutions and associated actors through the mediation of the OPLB. This partnership was the result of the participation of members of civil society in the Advisory Council of the OPLB from the beginning of the project. As a new territorial institution that is collectively managed, the OPLB also provided a new career opportunity for local politicians and activists. The presidency of the OPLB was assumed by various funding institutions through an implicit principle of changeover (Departmental Council, Regional Council, Intermunicipal Community for the Basque Culture the state preferred to leave the presidency to the elected officials). The presidency was first given in 2005 to Max Brisson, a right-wing elected member of the departmental General Council. In 2011, he was followed by the socialist François Maitia, on behalf of the Regional Council. Thus, the consolidation and institutionalization of territorial expertise regarding factors such as language, culture and local development constituted a means of entry not only for moderate Basque nationalist activists, but also for local state representatives and for Basque politicians belonging to French national parties who were looking for new legitimacy and new strategies for acquiring an accumulation of mandates at the local level. Other coalitions appeared besides the OPLB. One of the most important is the Hiru sareak (the three networks) community, which connects the three bilingual and immersive educational networks. Its creation responded to the demand by parents for increased investment in Basque language education since the number of children studying in Basque increased from 2907 in 1993 to 6149 in 2004 (Betbeder, 2006).

Finally, despite their easy access to the policy process, these new coalitions were unable to prevent the organization of several protests led by outsiders against the current mainstream Basque language policy. At the margins of the institutional debate, cultural pro-Basque associative movements (for example, Behatokia - the Observatory; Euskararen Gizarte Erakundeen Kontseilua - Council of Basque Civil Society Organizations; Euskal Konfederazioa Basque Confederation; Euskal Herrian Euskaraz In Basque in the Basque Country; and AEK) remained critical: according to these ethnolinguistic movements, the use of language experts and sociolanguage statistics by public authorities only contributed to depoliticizing the debate and excluding social movements from the negotiations. Moreover, the cross-border movements Euskararen Gizarte Erakundeen Kontseilua (Council of Social Actors in Favour of the Basque Language) and AEK repeatedly argue in favour of the legal recognition of the Basque language by the French state and a specific département for the French Basque Country as two necessary conditions for any successful linguistic policy. As one of the members of AEK stated: 'We don't want any special rights. We only claim more equality; I mean the possibility of speaking Basque in the Basque Country' (interview in Bayonne, 2007). In the minds of radical ethnolinguistic activists, these two conditions are intimately linked: an efficient language policy should make the learning and use of Basque compulsory (Renteria, 2009). That is why a Basque département would be necessary to ensure the necessary language policy measures. As a full member of the OPLB, the French state (together with its partners) logically has refused until now to support any compulsory dimension and maintained the principle of free choice.

\section{Repertoire of collective action: from the street to the negotiating table}

The scope of collective action of territorial actors participating in the Basque language policy has changed. In fact, a shift has occurred from street struggles to discussion with political authorities. Indeed, a new generation of actors accepts that it must participate in institutional forums and official discussions with local, regional and state representatives. Through its new policy instruments, the OPLB 
began to organize actions that until then had been led by associations, as in the case of the promotion of Basque in municipalities, formerly managed by Euskal Konfederazioa. However, the range of collective actions of Basque language defenders remains partially based on traditional tools of protest such as popular demonstrations, petitions, sit-ins and performances.

During the 2007-10 period, this classical repertoire of contention was used on two occasions. An initial series of campaigns was directed towards the French state and requested a change in the state's policy regarding regional languages and making Euskera an official language. These mobilizations, like the huge Deiadar (the Call) demonstration held in Bayonne on 24 October 2009, benefited from significant support from social movements but were also backed by local elected officials and business networks, not exclusively from the abertzale (leftist Basque nationalist) sphere. These actors also criticized the new territorial institutions, as illustrated by the demonstration held in November 2007 in front of the OPLB by the cross-border association Euskal Herrian Euskaraz to condemn the weakness of the current language policy and the present institutional framework of the French Basque Country. Finally, and subsequently, the ongoing institutionalization of a language policy in the French Basque Country also provoked an increase in the intensity of the defensive Jacobin reaction, especially in the Basque coastal zone where local politicians fear the expansion of radical Basque nationalism in France (Thomas, 2005).

\section{Cross-border cooperation as compensation for the northern language policy weaknesses}

As mentioned in the introduction, the effects of cross-border mobilizations must be taken into account in understanding the institutionalization of the language policy in the French Basque Country since the mid-1980s. A survey conducted in the mid1990 s on the projects funded by the pioneering Aquitaine-Euskadi Common Fund - a regional public joint venture created in 1990 for funding crossborder projects between Aquitaine and Euskadi provided evidence that, among the many proposed projects, cultural and linguistic ones attracted more actors from Euskadi and the French Basque Country than from the rest of the Aquitaine region (Itçaina et al., 1997). In concrete terms, the Common Fund had become 'an essential instrument for financing cultural initiatives in the French Basque Country with money from the Spanish Basque autonomous government', as stated by a member of the former Basque government (interview in Barcelona, 2009).

Such cultural collaboration was not easy, however, because the Spanish Basque regional government had no real French Basque counterpart to deal with and had to make arrangements with the Aquitaine Regional Council. Moreover, institutional relations between Euskadi and the Aquitaine region were and still are affected by a deep financial and legal asymmetry because the budget of the Basque Autonomous Community is more than 10 times greater than that of any French region. Last but not least, from 1980 to 2009 there was a profound gap between the views of the Regional Council of Aquitaine, which had been controlled by right- or left-wing French parties since 1986, and of the Autonomous Basque Community, which was ruled by Christian democrat Basque nationalists of the Partido Nacionalista Vasco (PNV - Basque Nationalist Party) with regard to interregional cooperation. Whereas the former supported the maintenance of strong nation-states, the latter favoured a deeper transfer process aimed at seizing new resources and competences from the Spanish central state.

The new model of territorial governance in the French Basque Country that was inaugurated in the 1990s and 2000s helped to overcome the limits of these official cross-border relationships. As expected, the creation of the 'pays' Pays Basque and the subsequent launching of the OPLB in 2005 intensified cooperation between the public authorities: the southern regional government had an institutional counterpart in the north. A series of structural agreements were made between the OPLB (2006) and the Euskadi government concerning concrete issues: cofunding of linguistic projects emanating from civil society actors, official cross-border recognition of a linguistic diploma, cross-border television broadcasts, a cross-border sociolinguistic survey every five years (OPLB interview, Bayonne, 2011). 
The present cross-border linguistic relationship can be described in general terms of support from the southern actors directed towards the northern ones. This support took two forms: transnational associative networks organized on a Basque 'national' basis and institutional support from southern public bodies for northern associations. Among the cross-border social movements, Amado Borthayre (2006) distinguished between those that aim to lobby the representative institutions to reinforce the current language policy (Euskal Herrian Euskaraz, Kontseilua-Euskal konfederazioa, parents' associations of public bilingual schools) and those that propose an alternative policy model. Far from limiting themselves to lobbying, the latter considered themselves to be creating real educational and social alternatives. Significant examples are the immersive associative schools (ikastola) managed by the Seaska association, the AEK association offering Basque lessons to adults, or the Basque Summer School (Udako Euskal Unibertsitatea). All of these experiences share four characteristics: (a) their activity and structure are transnational; (b) their internal organization is based on democratic principles of collective decisionmaking and horizontal power relations; (c) many of these initiatives depend on southern Basque financial resources (which reproduces the institutional asymmetry mentioned earlier at the civil society level); and (d) they use Europe as a tool for enhancing crossborder collaboration and promoting Euskera, notably via the European Bureau for Lesser Used Languages. These networks demonstrated a high learning capacity with regard to European norms and programmes. As evidence, in 2009, the federation of the ikastola from both sides of the border created a European Cooperative Society to facilitate mutual help between the ikastolak from Euskadi and Navarre and Iparralde, thus mobilizing both the new European norms and the institutional opportunities related to social economy, minority languages and crossborder relationships.

Regarding the support provided by the government of Euskadi for Iparralde associations, these relationships took at least two forms. First, the southern autonomous government, when it was controlled by the PNV and its allies, intervened in the French Basque Country by funding educational networks and Basque-speaking media. Secondly, new public policies were set up jointly by public institutions from both sides of the border. The establishment of a cross-border radio station (Antxeta irratia) among Hendaye, Irun and Hondarribia illustrates this point. In the same vein, beginning in 1996, sociolinguistic surveys were conducted jointly on both sides of the border by the Basque government in association with Navarrese and French Basque actors. More generally, cross-border collaboration ranked among the three priorities of the Basque Country Development Council in their Pays Basque 2020 prospective programme, together with territorial reciprocity (between the coastal zone and the inner countryside) and sustainable development. The Spanish Basque government also dedicated a specific budget heading to Basque initiatives implemented outside of its territory. Its scope includes the Basque diaspora living in America but also in the neighbouring area of the French Basque Country. Since 2009, the foreign cultural policy of the Spanish Basque government has been managed by the Instituto Etxepare (Departamento de Cultura, 2007), which can be seen as a step towards the institutionalization of cross-border cultural policy.

\section{Conclusion}

France is usually portrayed as a monolingual country where regional differences have disappeared. This is a partial vision of a much more complex situation. As this paper has demonstrated, some regions have maintained their own local cultural features despite the cultural centralization policy exerted by the central state. From this point of view, the case of the French Basque Country is interesting because language policy issues are debated by a broad range of very different actors, from political representatives belonging to French national parties to Basque nationalist activists.

This paper has focused on the progressive institutionalization of Basque language politics in Iparralde. Obviously, this language policy cannot be compared with the long-standing programmes that have existed in Hegoalde since the 1980s. The respective financial aspects are different, and a great degree of legal 
constraint is imposed on Hegoalde citizens regarding the learning and speaking of Basque. In any event, this policy innovation must be considered a real novelty in the context of the Fifth French Republic.

The rise of this policy has numerous causes. As stated at the beginning of this paper, the rise of this policy cannot be adequately tackled only with endogenous variables: the new French polity, the new institutional capacities achieved after decentralization, the new relationship with central state services, the creation of stable territorial coalitions between civil society and local representatives, or the new and more peaceful repertoire of collective action by activists. That is why it is so necessary to reintroduce exogenous factors: the rise of crossborder relations between French and Spanish actors, which favoured the institutionalization of a regional language policy in Iparralde.

Cole (2006) has provided an overview of French decentralization from three distinct conceptual perspectives. First, decentralization in France is part of a broader programme of state reform, part of a drive by central governors to divest themselves of unwanted or inflationary functions. Second, decentralization can be read as part of an iterative process of local and regional capacity-building. Capacity is defined 'in terms of viable institutions, embedded inter-institutional relationships, political leadership and policy entrepreneurship, asymmetry in policy delivery and the development of local and regional public arenas' (Cole, 2006: 32). Third, decentralization in France is shaped by new forms of identitybased territorial mobilization that challenge the centralist model of the unitary state.

Clearly, the initial institutionalization of a Basque linguistic policy in the French Basque Country resulted from an encounter between some of these readings. It constitutes an accommodation between a strong identity-based territorial mobilization and a new framework for territorial governance that allows room for a policy of recognition of Basque culture and language. However, this original institutional accommodation might also be perceived by the state as an institutional innovation sui generis, adapted to a reluctant border territory but not necessarily replicable within other territorial configurations.
Some questions remain unresolved. The first relates to the appropriateness of the Basque pattern of territorial governance, given the new developments of decentralization in France. The 2010 decentralization reform (the ending of the pays, the merging of regional and departmental elected officials, the metropolization of big cities) reinforces the first reading proposed by Cole: the priority for the state is to reduce public spending by sharing its cost. Despite this context, it is probable that the Basque participatory institutions will last, given their political role, although their future remains uncertain.

The second question involves the actors in the current Iparralde language policy. This paper has shown the complex bargaining between several civil society and political representatives, but it seems that the recent professionalization of language issues has already tended to 'rationalize' the attributes of different policy actors. The ongoing process of institutionalization of language policy requires new forms of knowledge and expertise, new technical and political skills. It will be interesting to focus on this process of expertise-building and to assess the transfer of knowledge and patterns that will probably occur (from the Spanish Basque Country? from other French and European models?).

Another question relates to the possible consequences for the French Basque Country of the political shift in the Spanish Basque autonomous government that occurred in March 2009. The defeat of the PNV after 30 years at the head of the Basque Country could have at least two outcomes. On the one hand, according to a path-dependent mechanism, the new non-Basque nationalist coalition led by the Spanish Socialist Party could decide - which seemed to be the case in 2010-11 with regard to the partnership with the OPLB - to follow the policy trend of the PNV by maintaining its support for Iparralde media, schools and cultural projects. On the other hand, in the present context of budget reductions and the harsh opposition between Basque and non-Basque nationalists, the new Euskadi executive could choose not to add more fuel to the fire. This means that it could focus its future policy on domestic issues such as unemployment, health, housing or transport and that it could stop 
(or weaken) its logistic support for French actors promoting the Basque language.

Finally, from a more theoretical viewpoint, it could be interesting to test our hypothesis of 'compensation for institutional weakness by exogenous variables' in alternative fields. At first glance, this hypothesis could be tested in the Catalan case, where there is a configuration that is very similar to the Basque one, with a common language and with institutional and social ethnolinguistic mobilization across the Franco-Spanish border. But it might also be tested in other contexts, such as Northern Ireland, where the historical legacy of violence has undoubtedly played a major role in the shaping of crossborder language, culture and identities.

\section{References}

Ahedo Gurrutxaga I (2004) El euskera desde fuera en Iparralde. Revista Internacional de Estudios Vascos 49(2): 383-434.

Ahedo Gurrutxaga I (2005) Nationalism in the French Basque Country. Regional and Federal Studies 15(1): 75-91.

Amado Borthayre L (2006) Los movimientos sociales 'nacionales' de la lengua: Creadores de políticas públicas 'nacionales' vascas? In: Letamendia P (ed.) Acción colectiva Hegoalde-Iparralde. Madrid: Fundamentos, 285-299.

Barral P (1974) Idéal et pratiques du régionalisme dans le régime de Vichy. Revue Française de Science Politique 24(5): 911-939.

Baxok E (2008) Hizkuntza antolaketaren bideetan. Bat, Soziolinguistika Aldizkaria 67(2): 67-77.

Baxok E, Etxegoin P, Lekumberri T, Martínez de Luna I, Ahedo I, Mendizabal L, Itçaina X and Jimeno R (2006) Identidad y cultura vascas a comienzos del siglo XXI. San Sebastián: Sociedad de Estudios Vascos.

Betbeder T (2006) Euskararen Erakunde Publikoa. Hizkuntza politika bat egituratzen IparEuskal Herrian. Bat, Soziolinguistika Aldizkaria 59(1): 41-58.

Blanchet P, Breton R and Schiffman H (eds) (1999) Les langues régionales de France: Un état des lieux à la veille du XXIe siècle. Louvain: Peeters.

Borthayrou J, Etcheverry-Ainchart P and Garat M (2005) Le mouvement culturel basque. 1951-2001, Tome 2. Bayonne: Elkar.

Bourdieu P (1982) Ce que parler veut dire. L'économie des échanges linguistiques. Paris: Fayard.
Bourdieu P and Boltanski L (1981) Le fétichisme de la langue. Actes de la Recherche en Sciences Sociales 3: 2-17.

Cerquiglini B (2003) Les langues de France. Paris: Presses Universitaires de France.

Chaussier JD (1996) Quel territoire pour le Pays Basque? Les cartes d'identité. Paris: L'Harmattan.

Clairis C, Costaouec D and Coyos JB (eds) (1999) Langues et cultures régionales de France. Etat des lieux, enseignement, politiques. Paris: L'Harmattan.

Cole A (2006) Decentralization in France: Central steering, capacity building and identity construction. French Politics 4(1): 31-57.

Cole A and Loughlin J (2003) Beyond the unitary state? Public opinion, political institutions and public policy in Brittany. Regional Studies 37(3): 265-276.

Cole A and Williams C (2004) Institutions, Identities and lesser-used languages in Wales and Brittany. Regional and Federal Studies 14(1): 554-579.

Council of Europe (1992) European Charter for Regional or Minority Languages, Strasbourg. URL (accessed 26 October 2011): http://conventions.coe.int/Treaty/ en/Treaties/html/148.htm.

Coyos JB (2004) Politique linguistique. Langue basque et langue occitane du Béarn et de Gascogne. Bayonne: Elkar.

Coyos JB (2008) Hizkuntz politika Ipar Euskal Herrian: nondik nora? Ibilbidearen azterketa. Bat, Soziolinguistika Aldizkaria 2: 79-102.

Departamento de Cultura (2007) Conferencia internacional sobre politicas culturales. Vitoria-Gasteiz: Servicio Central de Publicaciones del Gobierno Vasco.

Elias N (1982) The Civilizing Process: Power and Civility. New York: Pantheon Books.

Fishman JA (ed.) (2000) Can Threatened Languages Be Saved? Clevedon: Multilingual Matters.

Garat M and Aire X (2009) Seaska, 40 urte euskararen alde. Donostia: Elkar.

Harguindéguy JB and Ballester López M (2007) Acción colectiva y enseñanza de las lenguas regionales en Francia (1951-2006). Una primera aproximación. Revista Española de Ciencia Política 16: 89-108.

Harguindéguy JB and Cole A (2009) La politique linguistique de la France à l'épreuve des revendications ethnoterritoriales. Revue Française de Science Politique 59(5): 939-966.

Itçaina X, Palard J and Vignes B (1997) Politique institutionnelle ou mobilisation sociale? Le Fonds commun Aquitaine-Euskadi. In: Palard J (ed.) L'Europe aux frontières. Paris: Presses Universitaires de France, 131-154. 
Jacob J (1994) Hills of Conflict: Basque Nationalism in France. Reno: Reno University Press.

Jones R and Fowler C (2007) Where is Wales? Narrating the territories and borders of the Welsh linguistic nation. Regional Studies 41: 89-101.

Judge A (2000) France: One state, one nation, one language. In: Barbour $\mathrm{S}$ and Carmichael C (eds) Language and Nationalism in Europe. Oxford: Oxford University Press, 44-82.

Keating M (2001) Rethinking the region: Culture, institutions and economic development in Catalonia and Galicia. European Urban and Regional Studies 8(3): 217-234.

Kuus, M (2011) Whose regional expertise? Political geographies of knowledge in the European Union. European Urban and Regional Studies 18: 275-288.

Laborde D (1999) Politique culturelle et langue basque. In: Blanchet P, Breton R and Schiffman H (eds) The Regional Languages of France: An Inventory on the Eve of the XXIst Century. Louvain-la-Neuve: Peeters, 141-160.

Lascoumes P and Le Galès P (2007) Sociologie de l'action publique. Paris: Armand Colin.

Letamendia F (1997) Basque nationalism and cross-border co-operation between the southern and northern Basque countries. Regional and Federal Studies 17(2): 25-41.

Linz J, Orizo FA and Vila Madrid D (1986) Conflicto en Euskadi. Madrid: Espasa-Calpe.

Loughlin J (1985) A New deal for France's regions and linguistic minorities. West European Politics 8(3): 101-113.

Mansvelt Beck J (2005) Territory and Terror: Conflicting Nationalisms in the Basque Country. London: Routledge.

Mezo J (2008) El palo y la zanahoria: Política lingüistica y educación en Irlanda y el País Vasco. Madrid: Centro de Estudios Políticos y Constitucionales.
OPLB [Office Public de la Langue Basque / Euskararen Erakunde Publikoa] (2006) Un objectif central: Des locuteurs complets. Un objectif: Les jeunes générations. Bayonne: OPLB.

Oronos M (2002) Le mouvement culturel basque, 1951-2001, Tome 1. Bayonne: Elkar.

Oronos M, Etxezarreta L and Arbelbide X (2008) Le mouvement culturel basque 1951-2001, Tome 3. Bayonne: Elkar.

Poignant B (1998) Rapport sur les langues et cultures régionales. Paris: Ministère de la Culture.

Renteria A (2009) Legeari beha, hizkuntzaren geroa hizpide. Berria, 29 December.

Tejerina B (1999) El poder de los símbolos. Identidad colectiva y movimiento etnolingüística en el País Vasco. Revista Española de Investigación Sociológica 88: 75-105.

Thomas P (2005) Usage et dénonciation de la notion d'ethnie basque par l'anti-départementalisme en Pays Basque nord. Lapurdum 10: 233-246.

Touraine A, Dubet F, Hegedus Z and Wievorka M (1981) Le pays contre l'Etat: Luttes occitanes. Paris: Seuil.

Urteaga E (2004) La politique linguistique au Pays basque. Paris: L'Harmattan.

Viceconsejería de Política Lingüística (2006) IV Encuesta Sociolingüistica. Vitoria: Gobierno Vasco.

Weber E (1977) Peasants into Frenchmen. The Modernization of Rural France. London: Chatto \& Windus.

Wright S (2000) Jacobins, regionalists and the Council of Europe's Charter for Regional and Minority Languages. Journal of Multilingual and Multicultural Development 21(5): 414-425. 